\title{
The response to selection during first lactation on the phenotypic and genetic trends in the Elsenburg Holstein-Friesland herd
}

\author{
C.J.C. Muller ${ }^{\#}$ and J.A. Botha \\ Animal Production, Private Bag X1, Elsenburg 7607, South Africa
}

\begin{abstract}
A breeding policy to improve milk production in the Elsenburg Holstein-Friesland herd was adopted in 1984. Cow selection was based on partial (90 days) and completed (300 days) lactation records of $4 \%$ fat corrected milk and protein yields during first lactation. Dutch type AI proven bulls as well as young unproven bulls from the herd were used initially. Holstein type bulls with the highest breeding value predictions (BV's) for milk and component yields were used since 1987. The phenotypic and genetic trends in milk yield for first lactation cows of the herd were derived from an animal model analysis conducted by the ARC-Animal Improvement Institute. The phenotypic trend for milk yield in the Elsenburg HolsteinFriesland herd was positive, amounting to $212 \mathrm{~kg}$ per year $\left(\mathrm{R}^{2}=0.88\right)$. Regression of average BV's on production year prior to 1984 suggested no change in genetic merit of first lactation cows over that period $\left(\mathrm{R}^{2}=0.35\right)$. Average BV's of first lactation cows in the Elsenburg Holstein-Friesland herd subsequently improved by $92.3 \mathrm{~kg} /$ year $\left(\mathrm{R}^{2}=0.96\right)$. This improvement was higher than corresponding genetic change in the national herd over the same period $\left(76.4 \mathrm{~kg} /\right.$ year; $\left.\mathrm{R}^{2}=0.98\right)$. Rigorous culling of inferior milk producing cows on first lactation records and using bulls with high breeding values for milk and component yields had a marked improvement on the genetic merit of first lactation cows in the herd. This improvement on the genetic merit of first lactation cows in the herd amounted to $1200 \mathrm{~kg}$ milk per cow over the 13 -year period it was practiced.
\end{abstract}

Keywords: Phenotypic change, genetic change, selection response, first lactation cows, milk yield, HolsteinFriesland.

${ }^{\#}$ Corresponding author. E-mail: carelm@elsenburg.com

\section{Introduction}

The milk yield of dairy cows is of major economic importance. Each cow has a basic maintenance requirement at a fixed cost. With a higher milk yield per cow, productive efficiency increases and fixed costs such as maintenance needs decrease as a percentage of total costs (Muller, 2001). The milk yield of dairy cows may be improved by genetic and environmental (feeding, housing, etc.) means. The main goal for dairy cattle selection programmes is to maximise genetic progress and profitability of production (Abdullah \& McDaniel, 2000b). The key to genetic progress is the use of sires with high breeding values for milk and component yields (Abdullah \& McDaniel, 2000a).

Little attention, however, has been given to the effect of the systematic culling of inferior producing dairy cows on the average milk yield of cows in a dairy herd. Culling based on milk yield should preferably be done during first lactation, as milk yield is then at its lowest point in a cow's productive life. First lactation cows generally make the smallest contribution to the total milk production of a dairy herd. There is also a positive correlation ( 0.22 ) between level of first lactation milk yield and length of herd life (White \& Nichols, 1965). Norman et al. (1981) found that first lactation milk yield had a correlation of 0.56 with income per day of productive life.

Farmers are, however, generally not keen to cull cows during first lactation because of the high cost of rearing replacements (approximately 15\% of the dairy budget) and possibly the low monetary value of such animals. They are not prepared to sacrifice normal healthy and possibly pregnant first lactation cows because of a low milk yield. Kulak et al. (1997) also noted that dairy farmers are reluctant to accept first lactation production as an adequate and sole indicator of a cow's lifetime profitability. Identifying low producing first lactation cows is specifically a problem in small herds as the number of cows in milk at the same time makes comparison difficult. This may be overcome by calculating a threshold value for selection based on production parameters of first lactation cows during a previous time period (i.e. 5 years) (Heydenrych \& Paulse, 1981). 
In this study the effect was determined of a breeding policy that included the selection of cows during their first lactations according to selection threshold values and selecting bulls on breeding values for production parameters on the phenotypic and genetic trends in a Holstein-Friesland herd.

\section{Materials and methods}

The study was conducted at the Elsenburg Experimental Station of the Department of Agriculture of the Western Cape over a 13 year period. Elsenburg is situated about $50 \mathrm{~km}$ east of Cape Town in the winter rainfall region of South Africa at an altitude of $177 \mathrm{~m}$, longitude $18^{\circ} 51^{\prime}$ and latitude $33^{\circ} 51^{\prime}$. The Elsenburg Holstein-Friesland herd was established in 1902 from Friesland cows bought from local breeders. Bulls were imported from Holland until 1960 while herd bulls were also used. The herd consisted of about 60 lactating cows most of the time. After the establishment of the artificial insemination (AI) industry in South Africa, semen from bulls from the local progeny testing schemes was used in the herd. Herd bulls were also used throughout on cows with breeding problems. No emphasis was placed on high milk yields in the breeding programme of the Elsenburg Holstein-Friesland herd prior to 1984. Line breeding for type was the main emphasis during the early years of the herd. A breeding policy to improve milk production parameters in the herd was adopted in 1984.

Initially the breeding programme concentrated on the selection of higher producing cows during first lactation. This was based on calculated threshold values for selection of $4 \%$ fat corrected milk (FCM) and protein yields. Both partial (90 days) and completed (300 days) lactation records were used. The correlation between 90 and 300 days 4\% FCM and protein yields was determined for all Holstein-Friesland cows $(\mathrm{n}=$ 63) that had completed a standard lactation period in the herd during the five year period prior to 1984. Since establishing threshold values for selection, the 90- and 300-days FCM and protein yields of all first lactation cows were determined after each milk recording test. Cows producing less than the threshold values for selection were culled from the herd. Cows with borderline production levels at 90-days were given a second chance to prove themselves at 300-days. Threshold values for selection for both 90- and 300days production were calculated based on the average and standard deviation (s.d.) of 4\% FCM and protein production, i.e. $((0.2533 *$ s.d. $)+$ average $)$ to affect a $40 \%$ selection rate (Heydenrych \& Paulse, 1981).

To maintain the aesthetic value of the herd in terms of type, local AI proven bulls from Dutch origin as well as young unproven bulls from the herd were used. Because of the small number of Dutch type bulls available in South Africa at that time, Holstein bulls with the highest breeding value predictions for milk and component yields were used from 1987 onwards. This was maintained until 1998 when a new breeding policy was adopted.

First lactation cows were kept initially on kikuyu pasture during the day. Oat hay was also provided in feed troughs at night. A concentrate supplement was fed twice a day before milking. Amounts were allocated according to milk yield. From 1987 onwards a complete diet consisting of oat and lucerne hay, wheat, maize, wheaten bran, cottonseed oil cake meal, fish meal, feed lime and salt was provided on an $a d$ libitum basis to all cows during first lactation. They were also kept separate from the rest of the cow herd in an effort to reduce competition at the feed trough with bigger and older cows. This feeding programme has been maintained to ensure similar environmental conditions to all first lactation cows.

Production parameters for all cows $(n=224)$ that had completed a standard lactation period in the Elsenburg Holstein-Friesland herd from 1978 to 1997 were obtained from the National Milk Recording Scheme. Estimated breeding values of these parameters were derived for each cow from an animal model analysis conducted by the Animal Improvement Institute of the Agricultural Research Council. Genetic and phenotypic trend estimates were obtained by regressing mean annual estimated breeding values and mean production performances on production year. Two separate linear regressions were fitted, viz. from 1978 to 1984 and from 1984 to 1997, to describe the two distinct periods in which different selection procedures were applied. Regression equations for each production parameter for the Elsenburg and the national Holstein-Friesland herds were tested separately for significance using the probability table as shown in Snedecor \& Cochran (1980). Differences between the intercept and slope of regression equations describing the phenotypic and genetic changes in the Elsenburg and national Holstein-Friesland herd were tested for significance using the methods described by Van Ark (1981).

\section{Results and discussion}

The phenotypic correlation of 90 days milk production traits with corresponding 300 days traits was high $(\mathrm{r}=0.83)$, suggesting 90 days productions to be reliable indicators of 300 days yields. Selection 
threshold values for protein and 4\% FCM yields used during the period from 1984 to 1997 are shown in Table 1.

Table 1 Selection threshold values for protein and 4\% fat corrected milk (FCM) yields for partial (90-days) and completed (300-days) lactation records used in the Elsenburg Holstein-Friesland herd

\begin{tabular}{cccc}
\hline \multirow{2}{*}{ Starting year } & Production parameters & \multicolumn{2}{c}{ Selection threshold values (kg) } \\
\cline { 3 - 4 } & & 90-days & 300-days \\
\hline $1984 / 85$ & Protein & 54 & 156 \\
& $4 \%$ FCM & 1560 & 4435 \\
$1989 / 90$ & Protein & 57 & 166 \\
& $4 \%$ FCM & 1660 & 470 \\
$1994 / 95$ & Protein & $67 *$ & 193 \\
& $4 \%$ FCM & $1930^{*}$ & 5464 \\
\hline
\end{tabular}

*From 1994/95 partial lactation records were based on 105-days

Selection threshold values increased over time as the production of cows increased because of a better feeding programme and higher genetic quality cows resulting from genetically superior bulls that were used in the herd. From 1994/95 partial lactation records were based on three milk recording tests with 35 day intervals (i.e. 105 days) instead of the usual 30 day intervals. The genetic trend for milk production of the Elsenburg and national Holstein-Friesland herds is shown in Figure 1.

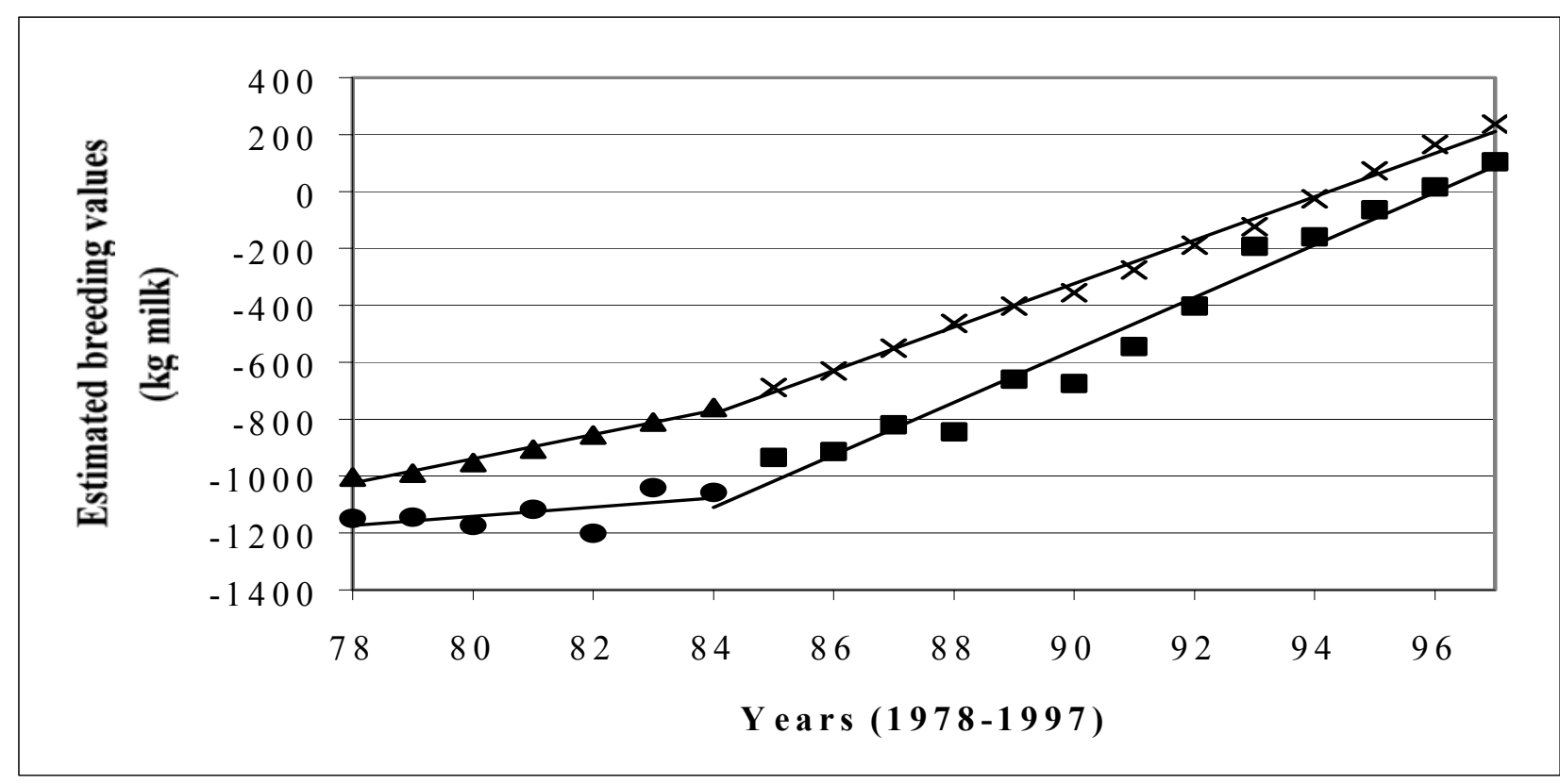

Figure 1 The genetic trends for milk production in the Elsenburg and national Holstein-Frieland herds from 1978 to 1984 (indicated by $\bullet$ and $\boldsymbol{\Delta}$ respectively) and from 1984 to 1997 (indicated by $\boldsymbol{\|}$ and $\mathrm{x}$ respectively)

The trends for other production parameters are shown in Table 2. Intercepts for genetic and phenotypic trends all deviated from zero $(\mathrm{P}<0.05)$. With the exception of protein yield, no genetic change in production parameters was observed in the Elsenburg Holstein-Friesland herd from 1978 to 1984 while the national herd showed improvements in all production parameters. From 1984 the genetic changes for milk and protein production in the Elsenburg herd $(\mathrm{P}<0.05)$ were all higher $(\mathrm{P}<0.05)$ than the genetic change for similar production parameters in the national herd. Fat and protein percentages, however, decreased more $(\mathrm{P}<0.05)$ in the Elsenburg herd than in the national herd. 
Table 2 The intercept ( \pm s.e.) and slope ( \pm s.e.) of the genetic trends for production parameters from 1978 to 1984 and from 1984 to 1997 in the Elsenburg and national Holstein-Friesland herds

\begin{tabular}{|c|c|c|c|c|c|c|}
\hline \multirow{2}{*}{$\begin{array}{l}\text { Production } \\
\text { parameters }\end{array}$} & \multicolumn{2}{|c|}{ Intercept } & \multicolumn{4}{|c|}{ Slope (kg/year) } \\
\hline & Elsenburg & $\begin{array}{c}\text { National } \\
\text { herd }\end{array}$ & Elsenburg & $\mathbf{r}$ & National Herd & $\mathbf{r}$ \\
\hline $1978-1984$ & & & & & & \\
\hline milk (kg) & $-1191 \pm 52^{\mathrm{a}}$ & $-1066 \pm 13^{b}$ & $16.2 \pm 9.8^{\mathrm{a}}$ & 0.59 & $42.5 \pm 2.5^{\mathrm{b}}$ & $0.99^{* * *}$ \\
\hline fat $(\mathrm{kg})$ & $-33 \pm 3^{a}$ & $-28 \pm 0.4^{\mathrm{b}}$ & $0.5 \pm 0.6$ & 0.41 & $1.1 \pm 0.1$ & $0.99 * * *$ \\
\hline protein $(\mathrm{kg})$ & $-34 \pm 1^{a}$ & $-29 \pm 0.4^{b}$ & $0.7 \pm 0.2^{\mathrm{a}}$ & $0.81 *$ & $1.1 \pm 0.1^{\mathrm{b}}$ & $0.99 * * *$ \\
\hline fat $(\%)$ & $0.18 \pm 0.04$ & $0.18 \pm 0.01$ & $-0.001 \pm 0.008$ & -0.08 & $-0.009 \pm 0.001$ & $-0.95 * * *$ \\
\hline protein $(\%)$ & $0.06 \pm 0.01$ & $0.09 \pm 0.002$ & $0.002 \pm 0.003^{\mathrm{a}}$ & 0.29 & $-0.004 \pm 0.0003^{b}$ & $-0.98 * * *$ \\
\hline $1984-1997$ & & & & & & \\
\hline milk (kg) & $-1756 \pm 66^{\mathrm{a}}$ & $-1316 \pm 22^{b}$ & $92.3 \pm 4.4^{\mathrm{a}}$ & $0.98 * * *$ & $76.4 \pm 1.5^{\mathrm{b}}$ & $0.99 * * *$ \\
\hline fat $(\mathrm{kg})$ & $-46 \pm 3^{\mathrm{a}}$ & $-36 \pm 0.6^{b}$ & $2.3 \pm 0.2$ & $0.96 * * *$ & $2.1 \pm 0.04$ & $0.99 * * *$ \\
\hline protein $(\mathrm{kg})$ & $-47 \pm 2^{\mathrm{a}}$ & $-35 \pm 0.7^{b}$ & $2.4 \pm 0.1^{\mathrm{a}}$ & $0.98 * * *$ & $2.1 \pm 0.05^{\mathrm{b}}$ & $0.99 * * *$ \\
\hline fat $(\%)$ & $0.31 \pm 0.04$ & $0.19 \pm 0.004$ & $-0.018 \pm 0.003^{\mathrm{a}}$ & $-0.88 * * *$ & $-0.011 \pm 0.0002^{\mathrm{b}}$ & $-0.99 * * *$ \\
\hline protein $(\%)$ & $0.14 \pm 0.03$ & $0.10 \pm 0.004$ & $-0.009 \pm 0.002^{\mathrm{a}}$ & $-0.80 * * *$ & $-0.006 \pm 0.0003^{b}$ & $-0.98 * * *$ \\
\hline
\end{tabular}

$* \mathrm{P}<0.05, * * \mathrm{P}<0.01, * * * \mathrm{P}<0.001$

${ }^{\mathrm{a}, \mathrm{b}}$ Values within rows for intercept and slope with different superscripts differ significantly $(\mathrm{P}<0.05)$

The phenotypic trends for production parameters in the Elsenburg and national Holstein-Friesland herds are shown in Table 3.

Table 3 The intercept ( \pm s.e.) and slope ( \pm s.e.) of the phenotypic trends for production parameters from 1978 to 1984 and from 1984 to 1997 in the Elsenburg and national Holstein-Friesland herds

\begin{tabular}{lll|ll|ll}
\hline \multirow{2}{*}{$\begin{array}{c}\text { Production } \\
\text { parameters }\end{array}$} & \multicolumn{2}{c|}{ Intercept (kg) } & \multicolumn{4}{c}{ Slope (kg/year) } \\
\cline { 2 - 7 } & Elsenburg & $\begin{array}{l}\text { National } \\
\text { herd }\end{array}$ & Elsenburg & \multicolumn{1}{c}{ r } & National herd & r \\
\hline $\mathbf{1 9 7 8}-\mathbf{1 9 8 4}$ & & & & & & \\
milk (kg) & $4540 \pm 398$ & $4041 \pm 84$ & $-39.1 \pm 75.2$ & -0.23 & $105.6 \pm 15.8$ & $0.95^{* *}$ \\
fat (kg) & $173 \pm 17$ & $154 \pm 3$ & $-2.4 \pm 3.2$ & -0.32 & $2.6 \pm 0.6$ & $0.89^{* *}$ \\
protein (kg) & $156 \pm 14$ & $136 \pm 3$ & $-2.3 \pm 2.6^{\mathrm{a}}$ & -0.37 & $3.2 \pm 0.6^{\mathrm{b}}$ & $0.92^{* *}$ \\
fat (\%) & $3.84 \pm 0.09$ & $3.82 \pm 0.03$ & $-0.023 \pm 0.018$ & -0.49 & $-0.030 \pm 0.005$ & $-0.94^{* *}$ \\
protein (\%) & $3.46 \pm 0.09$ & $3.35 \pm 0.02$ & $-0.023 \pm 0.017$ & -0.51 & $-0.004 \pm 0.004$ & -0.34 \\
& & & & & & \\
$\mathbf{1 9 8 4}-\mathbf{1 9 9 7}$ & & & & & & \\
milk (kg) & $3050 \pm 326$ & $3251 \pm 120$ & $212.3 \pm 21.6$ & $0.94^{* * *}$ & $183.3 \pm 8.0$ & $0.99^{* * *}$ \\
fat (kg) & $119 \pm 13$ & $120 \pm 5$ & $6.9 \pm 0.9$ & $0.91^{* * *}$ & $6.2 \pm 0.3$ & $0.98^{* * *}$ \\
protein (kg) & $130 \pm 15$ & $115 \pm 4$ & $4.9 \pm 1.0$ & $0.81^{* * *}$ & $5.1 \pm 0.3$ & $0.98^{* * *}$ \\
fat (\%) & $3.82 \pm 0.21$ & $3.65 \pm 0.03$ & $-0.015 \pm 0.014$ & -0.31 & $-0.007 \pm 0.002$ & $-0.71^{* *}$ \\
protein (\%) & $3.84 \pm 0.12^{\mathrm{a}}$ & $3.39 \pm 0.03^{\mathrm{b}}$ & $-0.036 \pm 0.008^{\mathrm{a}}$ & $-0.81^{* * *}$ & $-0.014 \pm 0.002^{\mathrm{b}}$ & $-0.90^{* * *}$ \\
& & & & & & \\
\hline
\end{tabular}

$* \mathrm{P}<0.05, * * \mathrm{P}<0.01, * * * \mathrm{P}<0.001$

${ }^{\mathrm{a}, \mathrm{b}}$ Values within rows for intercept and slope respectively with different superscripts differ significantly $(\mathrm{P}<0.05)$

From 1978 to 1984 all phenotypic trends for production parameters in the Elsenburg herd were negative albeit not significantly $(\mathrm{P}>0.05)$ because of large variations $\left(\mathrm{R}^{2} \leq 0.26\right)$. The milk yield of the national Holstein herd improved $(\mathrm{P}<0.01)$ during the same time by $106 \mathrm{~kg} / \mathrm{year}$. From 1984 the phenotypic trends for both the Elsenburg and national Holstein-Friesland herds improved annually $(\mathrm{P}<0.05)$ by 212 and 183 $\mathrm{kg}$ respectively. Fat percentage did not change $(\mathrm{P}>0.05)$ in the Elsenburg herd while the trend was negative in the national herd. The protein percentage in the Elsenburg herd declined as well $(\mathrm{P}<0.01)$

Abdullah \& McDaniel (2000b) found annual genetic changes in 3.75\% FCM and fat yields for North Carolina experimental dairy herds in different years. From 1950-1960, 1960-1970, 1970-1980 and 19801993 annual changes for FCM and fat yields were $-2.5,0.45 ; 27.9,0.75 ; 36.7,1.23$ and $94.7,3.46 \mathrm{~kg}$, 
respectively. Hansen (2000) reported that the genetic trend for Holsteins in the USA was 37, 79, 102 and $116 \mathrm{~kg} /$ year during the 1960s, 1970s, 1980s and for the period from 1990 to 1996, respectively. In the Elsenburg herd fat yield changed by $2.3 \mathrm{~kg}$ annually which is lower than the $3.46 \mathrm{~kg}$ change in the dairy herds reported by Abdullah \& McDaniel (2000a).

Single trait selection for milk yield effectively increased milk production of dairy cows in various projects conducted in the USA (Kelm et al., 2000). Genetic trends for milk yield in a high line in different regional herds ranged from 74 to $206 \mathrm{~kg} /$ year. The potential trends were generally in most instances higher than the genetic trend in the Elsenburg and National Holstein-Friesland herds $(89$ and $80 \mathrm{~kg} / \mathrm{year}$ respectively). This is probably an indication of the difference in the genetic potential of bulls available locally or in the USA.

Fat and protein percentages of first lactation cows in the Elsenburg herd were reduced from respectively 3.80 and $3.41 \%$ in 1984 to 3.52 and $3.15 \%$ in 1997 . Fat and protein yield, however, increased from 166 and $148 \mathrm{~kg}$ in 1984 to 259 and $234 \mathrm{~kg}$ respectively in 1997 . Selection for increased milk yields also reduced the fat percentage in regional herds in the USA (Kelm et al., 2000).

Selection in the Elsenburg herd was initially based on 4\% FCM and protein yield in an effort to prevent a reduction in fat and protein percentages. This could not be prevented completely as no information on the breeding values of fat and protein percentages of sires was available at the time of sire selection. Presently bulls are selected on the breeding values for fat and protein yield together with positive breeding values for fat and protein percentages.

The breeding value index that was used to rank AI sires in South Africa before the advent of BLUP breeding values was based on the prices paid for fat and protein. If a negative value on volume was used in the calculation of the breeding value index, the ranking of bulls could have been different, resulting in a different choice of sires.

Comparing milk yield responses in the Elsenburg and national Holstein-Friesland herds with genetic and phenotypic changes in the USA dairy industry is difficult because of large differences in environment, and specifically feeding and management. The local AI industry is small in comparison to the American industry. Only 40 bulls are tested annually in South Africa while in the USA the figure is more than a 1000 bulls per year. Bulls tested in South Africa are also progeny of American or European sires resulting in a genetic lag of at least one generation.

\section{Conclusions}

Identifying and culling inferior producing dairy cows during first lactation as well as using bulls with high breeding values for milk production parameters resulted in positive phenotypic and genetic trends for all milk production parameters in the Elsenburg Holstein-Friesland herd. In South Africa more attention should be given to the selection of sires for breeding purposes. The local AI industry should determine the breeding values of all bulls born annually in South Africa in terms of production parameters. This is already being done for all heifers born in herds taking part in the milk recording scheme. By ranking these bulls in terms of production parameters, the top 100 bulls could be identified and evaluated in the present progeny testing scheme. Bull mothers could also be identified by using estimated breeding values of heifers. Multiple ovulation and embrio transfer programmes could further be used to produce more heifers and bulls for evaluation in the local AI industry. The possible use of Interbull (MACE) breeding values should also be used to pursue these objectives.

\section{Acknowledgements}

The authors thank A. Shipman and his staff for the care and management of the animals in the Elsenburg Holstein-Friesland herd. S.W.P. Cloete at Elsenburg is also thanked for his valuable contribution towards establishing the breeding programme and comments regarding this manuscript.

\section{References}

Abdullah, J.M. \& McDaniel, B.T., 2000a. Genetic changes in milk, fat, days open and body weight after calving based on three methods of sire selection. J. Dairy Sci. 83, 1359-1363.

Abdullah, J.M. \& McDaniel, B.T., 2000b. Genetic parameters and trends of milk, fat, days open and body weight after calving in North Carolina experimental herds. J. Dairy Sci. 83, 1364-1370.

Hansen, L.B., 2000. Consequences of selection for milk yield from a geneticist's viewpoint. J. Dairy Sci. $83,1145-1150$. 
Heydenrych, H.J. \& Paulse, M.J., 1981. 'n Seleksieprogram vir die seleksie van verse in kleiner melkkuddes. University of Stellenbosch. Stellenbosch.

Kelm, S.C., Freeman, A.E., \& NC-2 Technical Committee, 2000. Direct and correlated responses to selection for milk yield: Results and conclusions to Regional Project NC-2, "Improvement of dairy cattle through breeding, with emphasis on selection". J. Dairy Sci. 83, 2721-2732.

Kulak, K.K., Dekkers, J.C.M., McAllister, A.J. \& Lee, A.J., 1997. Relationships of early performance traits to lifetime profitability in Holstein cows. Can. J. Anim. Sci. 77, 617-624.

Muller, L.D., 2001. Feeding the modern dairy cows. Proc. SA Large Herds Conf. Positioning for the future: Farm Business Strategy and Technology to 2010. 5-7 February 2001. The Tsitsikamma Conference Centre. South Africa. pp. 51-80.

Norman, H.D., Cassell, B.G., Pearson, R.E. \& Wiggans, G.R., 1981. Relation of first lactation production and confirmation to lifetime performance and profitability of Jerseys. J. Dairy Sci. 64, 104-113.

Snedecor, G.W. \& Cochran, W.G., 1980. Statistical methods. Iowa State University Press. Ames. Iowa. USA.

Van Ark, H., 1981. Eenvoudige biometriese tegnieke en proefontwerpe met spesiale verwysing na entomologiese navorsing. Wetenskaplike Pamflet no. 396. Dept. van Landbou en Visserye. Datametriese Dienste, Privaatsak X116, Pretoria 0001.

White, J.M. \& Nichols, J.R., 1965. Relationship between first lactation, later performance and length of herd life in Holstein-Friesian cattle. J. Dairy Sci. 45, 468-474. 